\title{
Innovation of Ideological and political education mode in Universities in the era of big data
}

\author{
Zhang Chunjie ${ }^{1}$, Zhiying Zhao ${ }^{* 2}$ \\ ${ }^{1}$ Department of Humanities and Social Sciences, BaoTou Medical College, Inner Mongolia 014040, \\ China \\ ${ }^{2}$ BaoTou Medical College, Inner Mongolia 014040, China
}

Keywords: Big data era, University ideological and political education mode, Inovation.

\begin{abstract}
In China, colleges and universities shoulder the important mission of conveying talents for society, researching the development of science and culture and building social civilization. Under the background of big data, college students are faced with Chinese collision of various social and cultural knowledge and values in the process of receiving higher education, so the study of the ideological and Political Education under the era of big data is very important. This article aims to discuss the connotation and characteristics of the big data era, and the problems faced by the ideological education in Colleges and universities in the big data era, and to study the innovative strategy of the ideological and political education model in the big data context.
\end{abstract}

\section{Introduction}

When the society enters twenty-first Century, accompanied by the rapid development of the Internet technology, a variety of Internet mobile terminal into people's lives, the amount of data for people to obtain information growth spurt, along with the arrival of the era of big data, and for people's work and life has brought the profound influence. Colleges and universities are active thinking, information intensive, the most frequent place for the application of network information technology, the work of teachers and students are also influenced by the era of big data to a great extent, in this context, the ideological and political education in Colleges and universities must conform to the big data brings the change of the times, ideological and political research on the education pattern of college is innovation in the era of big data. Next, the author will combine his own years of work experience, Briefly Talking about the ideological and political education model innovation in the background of big data era.

\section{The connotation and characteristics of big data Era}

Today's society, along with the continuous development of Internet technology, people have gradually entered the era of big data. In such an era, people obtain information more quickly and conveniently, and the knowledge reserve of the database is more abundant, which provides more convenience for people's life and work.

\section{The connotation of the big data times}

The so-called "big data era", its connotation is through the Internet information technology to form a huge and diverse, effective use of the data collection, the modern society is an important source for people to obtain information, for people's work and life has important influence. Moreover, the arrival of the big data era has generated many Internet technologies such as cloud computing and information technology, which has provided great convenience for people's lives. 


\section{Characteristics of the big data age}

The characteristics of the big data era is that people can get a lot of information based on Internet technology, has great convenience and information query and data transmission, and the divergence is conducive to resource sharing, promote the dissemination of information and knowledge innovation. According to the relevant report to the relevant departments revealed that in 1998, the use of global Internet users monthly traffic is only $1 \mathrm{MB}$, but in 2017, within a day, produced by the Internet information can accumulate 500 million disks, and the amount of the data is still continuing growth. The development of this kind of data blowout style is a great improvement for the progress of society and the convenience of people to obtain information resources. But note that, although the advent of the era of big data has brought to people's work and life to a great extent the great convenience, but also to the development of human activities from a huge challenge, if human work efficiency can not be beyond the information technology, so many jobs will have to complete a computer. Unemployment caused by staff.

\section{The opportunities and challenges faced by ideological and political education in Colleges and universities in the era of big data}

With the rapid development of Internet technology, the era of big data has come. This is like for students to open a new door for them, all kinds of information consultation with around the students, let the students' vision becomes more open, largely to meet the students' curiosity, expand the development of students' thinking, stimulate the students' desire for knowledge, to enhance the initiative the creation ability of students, so that they can better show themselves, and help students build confidence, to realize their value of life better. At the same time, the era of big data also indicates that the further development of information globalization, college students can in the first time to pay attention to the news of the world, to acquire knowledge through more channels, as far as possible to understand and grasp the new scientific information, is conducive to students' Autonomous Learning ability progress, strengthen the extension of extracurricular knowledge. However, the big data era, has also brought many adverse effects to college students, because the data is spread on the Internet, so the information, the information will be in addition to the scientific uneven in quality, positive knowledge, students will be exposed to some negative information, many students may get lost in big data the times, to establish a correct outlook on life and values, has caused the loss of its own moral values, eventually leading to the students' values deviate from the right track.

With the arrival of big data, the ideological and political education in Colleges and universities will inevitably usher in innovation, which is also a great challenge for University teachers. In the previous mode of Ideological and political education, the most important education way is effective communication between teachers and students, such as teachers according to students' psychological problems for students to talk or organize a topic, but this traditional model of Ideological and political education is easily influenced by the teaching ability and psychological factors, the teachers for the heart students' Ideological and emotional changes can not control, can not always work well. In the era of big data, students can express their own views and opinions, so casual, teachers can through data collection and gathering to analyze students' thoughts, and going through the disadvantages of the traditional ideological and political education work, the ideological and political work of innovation is a great breakthrough. In the teaching process, teachers can timely grasp students' ideological trends, and guide students to establish a correct outlook on life, world outlook and values, in the era of big data as the background, based on the Internet technology, the establishment of Ideological and political education work new platform. The traditional mode of Ideological and political education in Colleges and universities, the teaching process of teachers is mainly based on teaching methods, students are only indoctrination style learning, what the teacher says, what students learn. But in the era of big data, students can through the Internet information technology to active data mining, analysis of data, and the formation of self cognition, which resulted in the ideological and political understanding between teachers and students in different degrees, if students than teachers obtain information earlier, then it would be possible for students 
to form their own judgment, if students self judgment is correct, then everything is good, but if the students judge biased, it leads to the ideological and political work in Colleges and universities is extremely unfavorable situation, the ideological and political work of teachers received great challenges, reduce the efficiency of Ideological and political education, leading the loss of teachers.

The era of big data, ideological and political education in Colleges and universities, innovative methods

In the era of big data, want to carry on the innovation of the ideological and political education mode in Colleges and universities, first of all, to build a big data consciousness. With the continuous development of Internet information technology, big data era has come, now, the global Internet users has reached 3 billion 500 million people, this figure accounted for $17 \%$ of the world's population, in which China Internet users has reached 721 million, these data suggest that Internet information technology has entered our life, and everywhere. The era of big data, making the information coverage more widely, spread faster, at the same time, the problem is that information is more and more difficult to carry out effective control, so the process of college political education mode innovation thought in the era of big data must adapt to the characteristics of the era of big data, big data set consciousness so, in order to enhance the effectiveness of teaching. In the big data era, ideological and political workers should have the thinking for sensitive information data, students focus on the value orientation of the problems in the management of the usual process, and carry out the centralized collection, to find out the hidden rules, the use of reasonable and effective, and guarantee the effectiveness of teaching mode reform. On the innovation of Ideological and political education mode. The teachers should pay attention to the divergence of teaching methods, can not be bound by traditional thinking in teaching, but to try to reform the teaching methods, to find the link between data, to grasp the idea of dynamic changes of the students, to analyze the specific issues, to solve the problem of the different with practice, the ideological and political education, and help students establish a correct outlook on life, values, guarantee the effectiveness of teaching.

\section{Conduct comprehensive data analysis}

In the era of big data, it is necessary to carry out comprehensive data analysis in order to innovate the ideological and political education mode in Colleges and universities. In fact, our so-called ideological and political education, its essence is between the teacher and the students thought the exchange of information, communication and in the specific process by language and behavior to correct thinking. In the era of big data, the teacher can rely on the Internet information technology student data collection, production, but the key content in the middle age of big data innovation mode of College Ideological and political education is to analyze data, and grasp the idea of dynamic changes of the students through the analysis of the data, to provide basis of Ideological and political work reference data. College students are already adults, so the change of thought is more complex, based on this, ideological and political education workers must use the era of big data open, convenient, sharing the characteristics of multi-channel collecting students' confidence, comprehensive analysis, grasp the idea of dynamic students. At the same time, we should pay attention to, because college students are adults, so in their ideological and political education in the process, we must choose the right space, methods. For example, in peacetime, we can communicate well with WeChat, QQ and other chat software, make friends with students, and analyze the specific circumstances, to carry out covert teaching reform, let students better accept the era of big data under the mode of Ideological and political education.

\section{Combined with big data features, good student privacy protection}

In the era of big data, if we want to innovate the ideological and political education mode, we must adhere to the characteristics of the big data era, and do a good job of privacy protection of information. In the big data era, the data is open, information in the vast extent can be shared, therefore, in the process of innovation of big data era of Ideological and political education mode, we must combine the characteristics of the big data era, understand the characteristics of the era of big data, to do the work of confidential information reduce leakage of information. Analysis of the 
operation of collection, the workers of Ideological and political education in the ideological trend of students, but also to solve the problem of information security, to protect students' privacy, solve the problem of information security, improve the students' information and personal privacy protection. In the big data era, the requirements for talents in the ideological and political education in Colleges and universities are increasingly high, so the ideological and political education in Colleges and universities in the era of big data innovation in Colleges and universities should do a good job in training, efforts to improve the efficiency of work, training professional teachers, establish a large data awareness, on the other on the one hand, can also be the introduction of talent, specialized jobs in the community recruitment, comprehensive promotion of the ranks of Ideological and political education teaching level.

\section{Constructing advanced teaching and collecting team}

In the big data era, if we want to carry on the innovation of the ideological and political education mode, we must build the contingent of advanced teaching quantity. In the background of big data era, we want to realize the introduction of large data, analysis and practical application of the problem, we rely mainly on a professional team of teachers. In the past, the traditional ideological and political classes were taught by the teachers, and then the students were tested by the appearance of examinations. However, in the era of big data, we can use the dynamic comprehensive evaluation and process indicators, through the student's comprehensive quality evaluation, review, the hot social network of small and other aspects of comprehensive evaluation, the ideological and political education embodies the more comprehensive teaching objectives, so has been created with a high level of ideological and political education collection analysis of the team is very important. Establish and maintain the data collection team is mainly responsible for the work of data collection and data platform, pay attention to the students through the data to find the social news, and generate data tables automatically, specific work settings can be: data analysis team composed of computer teachers with experience, collection and generation table data, relationships between different kinds of data, help teachers based on the basis of effective teaching. The teaching team is composed of Ideological and political teachers, through the analysis of the data, tracking and handling problems timely, so that the ideological and political teaching mode more forward-looking, can carry out effective ideological and political education is to enhance students' ideological problems, treatment literacy, can not only improve the comprehensive quality of students' ideological and political also, to enhance teachers' theory of Ideological and political education, improve teachers' teaching level, guidance and timely answers to the students concerned, in order to build the "Ideological and political education assistant system - Analysis - Education" in one of the.

\section{Conclusion}

With the continuous development of Internet information technology, the era of big data is coming, and it brings great opportunities and challenges to the ideological and political education in China's colleges and universities. So, we are in the era of big data in the background, it has an important role to better understand the new era of Ideological and political work, the Era Connotation of big data research, combined with the characteristics of the era of big data, the pattern of Ideological and political education innovation in University, and to explore the new era of College Ideological and political work rules, improve work efficiency, help college students to establish a correct outlook on life, world outlook and values, promote the students' Ideological and political development.

\section{References}

[1], Li Huaijie, Xia Hu. Innovative research on Ideological and political education in Colleges and universities in the big data era [J]. ideological education research, 2015,05:48-51

[2] Zhu Zhu. Innovation of Ideological and political education mode in Universities in the era of big 
data [J]. educational modernization, 2016313:158-159

[3] Guo Jun. study on the innovation of Ideological and political education mode in Universities in the big data era [J]. Journal of Hubei Correspondence University, 20173004:54-55

[4] Xie Xie sleeve. Innovation of College Ideological and political education model in big data era [J]. China Educational Technology and equipment, 2017,08:97-99

[5] Xu Junli. Reflections on the innovative development of Ideological and political education in Colleges and universities in the big data era $[\mathrm{J}]$. Journal of Jilin business college, 20173303:111-114 